\title{
Pembangkit Sinyal Master Pada Sistem Navigasi LORAN-C menggunakan FPGA
}

\author{
Budi Syihabuddin ${ }^{1}$, Heroe Wijanto ${ }^{2}$, Iswahyudi Hidayat ${ }^{3}$ \\ ${ }^{1}$ Program Studi S1 Teknik Telekomunikasi, Fakultas Teknik Elektro, Universitas Telkom \\ ${ }^{2}$ Program Studi S2 Teknik Elektro Telekomunikasi, Fakultas Teknik Elektro, Universitas Telkom \\ ${ }^{3}$ Program Studi S1 Teknik Elektro, Fakultas Teknik Elektro, Universitas Telkom \\ 1,2,3 Jl. Telekomunikasi no. 1, Dayeuh Kolot, Bandung, 40257 \\ Email korespondensi : ${ }^{1}$ budisyihab@telkomuniversity.ac.id
}

Dikirim 07 Maret 2016, Diperbaiki 23 Maret 2016, Diterima 29 Maret 2016

\begin{abstract}
Abstrak - Navigasi saat ini menjadi hal yang sangat penting untuk menunjang kehidupan manusia, bahkan dapat digunakan sebagai sistem pertahanan dan ketahanan negara. Saat ini, sistem navigasi di Indonesia masih tergantung dengan sistem navigasi negara lain, khususnya yang berbasis satelit. Oleh karena itu, Indonesia membutuhkan sebuah sistem navigasi yang mandiri. LORAN-C adalah sistem navigasi terestrial yang menggunakan frekuensi ground wave dengan metode triangulasi, sehingga mempunyai radius cakupan yang luas. Pada penelitian ini dibuat subsistem pemancar sinyal master pada sistem navigasi LORAN-C dengan menggunakan FPGA. Penggunaan FPGA dimaksudkan untuk pembangkitan sinyal LORAN-C analog melalui sintesa digital (direct digital synthesis) pada tingkat baseband agar diperoleh format sinyal presisi tinggi. Dari hasil penelitian diperoleh sembilan pulsa master dengan spesifikasi sesuai dengan ketentuan sistem navigasi LORAN-C, lebar pulsa $300 \mu \mathrm{s}$, delay pulsa $700 \mu$ s serta amplitudo maksimum pada $\mathrm{t}=60-65 \mu \mathrm{s}$.
\end{abstract}

Kata kunci - LORAN-C, Ground Wave, Navigasi, Master, Slave, Sinkronisasi, FPGA.

Abstract - Nowadays navigation system is very important to support human life, it can even be used as a defense system of a country. Now, Indonesia relies on the navigation system of other countries, therefore Indonesia needs an independent navigation system. LORAN - C is a navigation system using ground wave with a triangulation system, so it has a wide radius. This research generates master signals in the LORAN - C navigation system by using FPGA. The FPGA is used to synthesize analog signal form to achieve hight precission signal format. From this research, the nine generated master pulses have the specifications in accordance with the provisions of LORAN - C navigation system, that has $300 \mu$ s pulse width, $700 \mu$ s pulse delay and a maximum amplitude at $\mathrm{t}=60-65 \mu \mathrm{s}$.

Keywords - LORAN-C, Ground Wave, Navigation, Master, Slave, Synchronization, FPGA.

\section{PENDAHULUAN}

Indonesia mempunyai luas wilayah sebesar 1.904.569 kilometer persegi [1]. Dengan kondisi seperti itu, Indonesia harus mampu mandiri dalam hal pertahanan dan ketahanan. Salah satu teknologi yang mendukung pertahanan dan ketahanan negara adalah teknologi navigasi. Navigasi yang biasa digunakan oleh masyarakat saat ini adalah GPS (Global Positioning System). Sistem GPS tersebut menggunakan satelit sebagai wahana. Beberapa negara yang mempunyai teknologi satelit dengan kemampuan navigasi antara lain Amerika Serikat dengan NAVSTAR, Rusia dengan GLONASS, Uni Eropa dengan Galileo, China dengan CNSS (Compass/BeiDou Navigation Satellite System) serta Jepang dengan QZSS (Quasi-Zenith Satellite System) [2].
Sistem navigasi digunakan antara lain untuk keperluan proses sinkronisasi dalam teknologi seluler serta dalam peralatan militer, sehingga jika tidak ada kemandirian dalam penguasaan sistem navigasi maka Indonesia akan sangat tergantung dengan negaranegara yang memiliki sistem satelit navigasi. Selain teknologi navigasi berbasis satelit, ada pula sistem navigasi yang memanfaatkan propagasi groundwave sebagai media transmisi yakni LORAN (Long Range Navigation) [2]-[6].

Sistem navigasi LORAN menggunakan gelombang radio untuk menentukan posisi suatu objek di atas permukaan bumi dengan frekuensi $100 \mathrm{kHz}$ [2]-[6]. Sehingga dengan frekuensi tersebut, bisa didapatkan cakupan navigasi yang luas tetapi pada pemancar harus memiliki dimensi dan power yang besar. Sistem navigasi LORAN ini menggunakan prinsip trianggulasi sehingga dibutuhkan minimal tiga 
pemancar, satu bertindak sebagai master dan dua lainnya bertindak sebagai slave [3], [7].

Pada penelitian [4] dilakukan perbandingan kinerja antara sistem navigasi GPS dengan sistem navigasi LORAN-C pada daerah urban dan daerah pegunungan. Begitu pula dengan [5] yang menganalisis performa dari GPS dan LORAN-C sebagai sistem penjejakan yang terintegrasi. Dari kedua penelitian tersebut, dapat disimpulkan bahwa sistem navigasi GPS dan LORAN-C dapat saling melengkapi satu sama lain.

Pada penelitian ini akan diusulkan pembangkit pulsa master LORAN-C sebagai pengujian awal sistem navigasi yang tidak menggunakan satelit sebagai wahana. Karena Indonesia belum memiliki sistem navigasi secara mandiri, penelitian ini membuat sistem navigasi LORAN-C yang didigitalisasi dengan menggunakan FPGA sebagai generator pulsa. Hasil yang diharapkan, FPGA dapat membangkitkan pulsa master dengan karakteristik sesuai dengan karakteristik pulsa LORAN-C.

Makalah ini terdiri dari 4 bagian dengan bagian pertama adalah pendahuluan, dan bagian kedua berisi tentang metodologi penelitian. Pada bagian kedua mencakup tentang teori dan spesifikasi dari pulsa master dari LORAN-C, perancangan sistem dan pengujian sistem. Pada bagian ketiga membahas hasil yang didapatkan kemudian pada bagian keempat berisi tentang kesimpulan dan saran.

\section{METODOLOGI PENELITIAN}

Pengerjaan penelitian ini mencakup beberapa aspek yaitu aspek teori meliputi karakteristik dari pulsa LORAN-C dan modulasi amplitudo, aspek perancangan meliputi perancangan blok sistem serta aspek pengujian untuk memverifikasi hasil rancangan. Pada bab ini dijabarkan langkah-langkah dan definisi dari penelitian yang dilakukan.

\section{A. LORAN (Long Range Navigation)}

Sistem navigasi LORAN menggunakan frekuensi $100 \mathrm{kHz}$ dengan lebar pita $20 \mathrm{kHz}$ [8], [9]. Dengan frekuensi sebesar $100 \mathrm{kHz}$, maka loss propagasi yang dirasakan tidak besar. Secara umum sistem navigasi LORAN-C terdiri dari beberapa stasiun pemancar, 1 buah pemancar sebagai master dan minimal 2 buah stasiun slave [3], [8], [9]. Masing-masing stasiun tersebut terpisah beberapa mil dengan membentuk konstelasi antar pemancar master dan beberapa pemancar slave, yang disebut dengan chain. Setiap pemancar tidak memancarkan pulsa secara kontinu namun periodik sesuai dengan selang waktu GRI (Group Repetition Interval). Dan juga, baik master atau slave akan memancarkan pulsa yang berbeda.

Pemancar master merupakan pemancar utama dari sel LORAN-C, berfungsi sebagai stasiun pertama yang memancarkan pulsa kemudian diikuti oleh stasiun slave dengan delay waktu tertentu. Untuk navigasi, statiun master memancarkan grup pulsa yang terdiri dari sembilan pulsa. Tiap grup pulsa mempunyai GRI yang berbeda untuk membedakan tiap sel LORAN-C [3],[8],[9]. Pada pemancar sekunder akan memancarkan delapan buah pulsa dengan ketentuan seperti pada Gambar 1 [3]. Perioda pulsa setiap pulsa sebesar $200 \mu$ s dengan selang waktu antar pulsa dalam satu grup sebesar $1000 \mu \mathrm{s}$, kecuali pada pulsa ke-9 pada grup master memiliki jarak $2000 \mu \mathrm{s}$. Oleh karena itu, untuk menghindari over-lapping, antar GRI dibuat cukup besar.

Pulsa master ataupun pulsa slave berupa sinyal analog dengan bentuk seperti pada Gambar 2 [9]. Sinyal tersebut dibangkitkan dengan persamaan envelope seperti pada persamaan (1) [9], yang dimodulasikan dengan frekuensi pembawa $100 \mathrm{kHz}$. Standar untuk lebar satu pulsa LORAN-C adalah 200 $\mu$ s dengan setengah amplitudo maksimum dicapai pada saat $30 \mu \mathrm{s}$ dan amplitudo maksimum pada saat $65 \mu \mathrm{s}$.

Proses yang dilakukan untuk membentuk pulsa LORAN-C seperti proses modulasi sinyal AM-DSBSC (Amplitude Modulation Double Side Band Supressed Carrier) dengan cara menumpangkan sinyal envelope kepada sinyal pembawa [10]. Dengan input berupa envelope sinyal yang mengikuti kaidah dari pulsa master dan slave yang kemudian dikalikan dengan sinyal pembawa berfrekuensi $100 \mathrm{kHz}$.

Seperti ditunjukkan pada Gambar 1, pertama akan dipancarkan sinyal master yang berisi sembilan pulsa, kemudian akan dideteksi oleh slave pertama, setelah itu slave pertama akan memancarkan delapan pulsa slave, kemudian slave kedua setelah mendapatkan sembilan pulsa master dan delapan pulsa slave pertama, akan memancarkan delapan pulsa slave kedua sehingga pada penerima LORAN-C akan menerima sembilan pulsa master, delapan pulsa slave pertama dan delapan pulsa slave kedua.

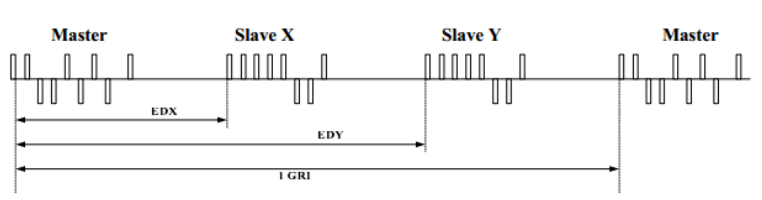

Gambar 1. Pulsa Master dan Slave LORAN-C

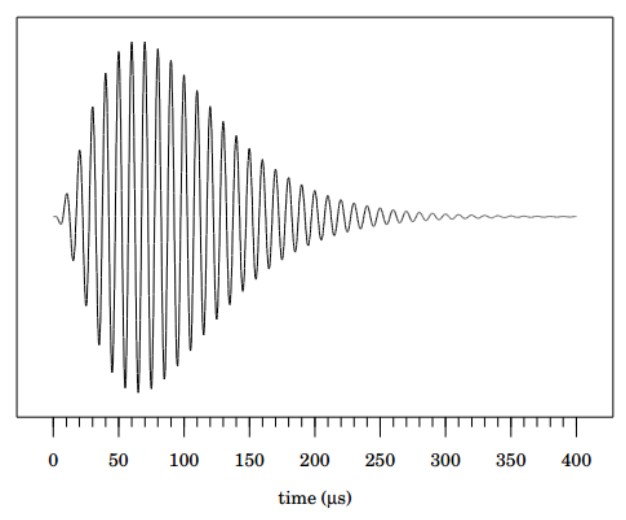

Gambar 2. Pulsa LORAN-C. 


$$
E(t)=\left\{\begin{array}{cc}
0 & t<\tau \\
A(t-\tau)^{2} \exp [-2(t-\tau) / 65] & \tau \leq t \leq 65+\tau \\
\text { tidak }- \text { didefinisikan } & t>65+\tau
\end{array}\right.
$$

\section{B. Desain Sistem Pemancar LORAN-C}

Pada penelitian ini, FPGA digunakan untuk mengurangi dimensi dari pemancar LORAN-C. Jika melihat dari frekuensi yang digunakan sebesar 100 $\mathrm{kHz}$, maka sistem akan memiliki antenna yang besar, begitu juga dengan daya pancar yang dibutuhkan. Dengan menggunakan FPGA, pembangkitan dilakukan secara digital, bukan analog. Untuk dimensi antena dapat diperkecil dengan menggunakan antena kumparan/loop [11]. Dengan antenna loop, pola radiasi yang didapatkan akan tetap omnidireksional namun dengan dimensi yang lebih kecil.

Untuk mendapatkan urutan sembilan pulsa master, dirancang sistem seperti yang ditunjukkan pada Gambar 3. Sistem didesian menggunakan 2 input, yaitu input pertama dari clock FPGA sebesar 100 $\mathrm{MHz}$ dan input kedua berupa reset untuk mengaktifkan sistem pembangkit pulsa master. Jika reset bernilai "1" maka sistem tidak bekerja dan jika reset bernilai " 0 " maka sistem akan menghasilkan pulsa master LORAN-C.

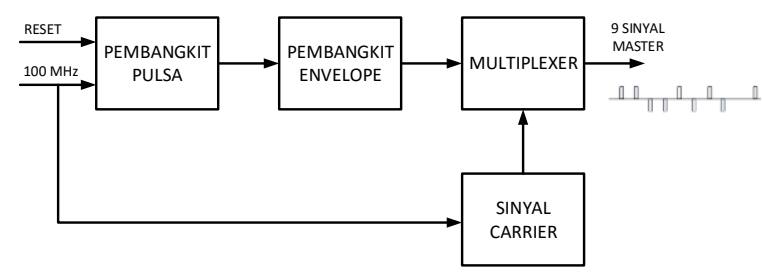

Gambar 3. Pembangkit Pulsa Master

1) Pembangkit pulsa

Pada pembangkit pulsa master, dibutuhkan pembangkit pulsa seperti pada Gambar 3 . Keluaran yang diharapkan sesuai dengan pulsa LORAN-C dengan lebar, jarak dan fasa pulsa yang bersesuaian. Sehingga dapat dibedakan oleh user sebagai pulsa master. Pembangkit pulsa dilakukan dengan cara menurunkan clock FPGA dari $100 \mathrm{MHz}$ menjadi $10 \mathrm{MHz}$ untuk mendapatkan periode bit 100 ns. Selain itu, untuk menghasikan fasa positif sebesar $300 \mu \mathrm{s}$ dibangkitkan logika " 01 " selama periode 300 us, serta untuk delay digunakan 7000 counter atau logika " 00 " selama $700 \mu$ s dan untuk fasa negatif digunakan logika " 11 " selama $300 \mu$ s. Pengaturan pembangkit pulsa ini disesuaikan dengan Gambar 3 sebagai ciri dari stasiun master.

\section{2) Pembangkit Envelope}

Envelope yang digunakan sesuai dengan persamaan (1), untuk menghasilkan envelope yang sesuai dengan sinyal LORAN-C, maka digunakan lebar envelope sebesar $300 \mu$ s, setengah amplitudo maksimum pada $\mathrm{t}=300 \mu \mathrm{s}$ dan amplitudo maksimum pada 65 $\mu$ s. Untuk mengubah persamaan tersebut agar dapat direalisasikan ke FPGA yang bekerja pada domain biner, maka dilakukan proses sampling nilai tegangan dari envelope. Dengan mengkuantisasi menjadi 8 bit, dan sampling data 30 buah. Output dari pembangkit pulsa sebesar $10 \mu \mathrm{s}$, sehingga digunakan 100 counter untuk membangkitkan setiap sample. Dengan 30 sample yang ada, maka untuk membentuk sinyal envelope dibutuhkan 3000 counter. Pembangkitan sinyal envelope harus pada timing yang sama dengan blok pembangkit pulsa, karena dari logika fasa positif, delay ataupun fasa negatif dari blok pembangkit pulsa akan dibangkitkan envelope yang bernilai positif, nol atau bernilai negatif.

\section{3) Sinyal pembawa}

Sinyal pembawa yang digunakan sebesar 100 $\mathrm{kHz}$, dibangkitkan dengan menggunakan counter dan juga clock dari FPGA serta reset, seperti desain pada pembangkit pulsa. Dengan frekuensi $100 \mathrm{kHz}$ maka periode sinyal pembawa sebesar 10 $\mu$ s dan periode clock FPGA yang telah dinaikkan menjadi $100 \mathrm{~ns}$, maka proses sampling 1 periode frekuensi pembawa dengan clock FPGA, akan didapatkan 100 sample berupa nilai dari tegangan pembawa untuk digitalisasi dengan menggunakan 8 bit kuantisasi. Sehingga untuk membangkitkan sinus selama $300 \mu \mathrm{s}$, dibutuhkan 3000 titik sample.

\section{4) Multiplexer}

Proses modulasi yang dilakukan dengan cara multiplexing, yang dalam domain waktu dilakukan perkalian antara sinyal envelope dengan sinyal pembawa. Jika sinyal envelope berfasa positif, maka nilai hasil modulasi akan berfasa positif. Sebaliknya jika envelope berfasa negatif, maka hasil modulasi akan berfasa negatif. Untuk delay, hasil modulasi akan bernilai nol karena tidak ada pulsa atau logic "00" sesuai dengan hasil blok pembangkit pulsa. Dengan output sinyal envelope 8 bit dan output sinyal pembawa juga 8 bit, maka hasil perkalian akan menjadi 16 bit.

\section{Pengujian Sistem}

Sistem yang dirancang meliputi stasiun master seperti pada Gambar 3. Gambar 4 merupakan proses pengujian yang dilakukan. Dari desain blok sistem yang telah dirancang, dilanjutkan dengan pemrograman bahasa VHDL pada modelsim untuk dilakukan simulasi lalu di-load ke FPGA dan di verifikasi dengan menggunakan logic analyzer. Cara melakukan verifikasi adalah dengan membandingkan hasil keluaran simulasi dengan proses realisasi pada FPGA. 


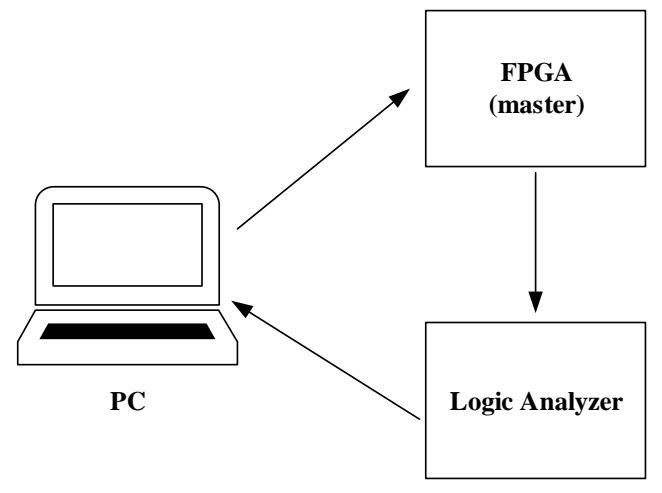

Gambar 4. Pengujian Pembangkit Pulsa Master

\section{HASIL DAN PEMBAHASAN}

Pada bagian ini membahas tentang hasil dari desain serta verifikasi hasil yang didapatkan, yaitu meliputi pembangkit pulsa master serta blok pembangkit pulsa, blok pembangkit envelope, blok sinyal pembawa, dan blok modulasi.

\section{A. Pembangkit Pulsa}

Pembangkit pulsa dalam penelitian ini dapat menghasilkan deret pulsa master dengan ketentuan seperti yang ditunjukkan pada Gambar 3. Hasil dari pembangkit pulsa ditunjukkan pada Gambar 5 dan 6 . Terlihat bahwa jumlah pulsa master adalah sembilan buah dengan periode satu grup pulsa master sebesar $9300 \mu$ s. Sesuai dengan perancangan blok pembangkit pulsa, fasa positif dikodekan dengan bit " 01 ", delay dengan kode bit " 00 " serta fasa negatif dengan kode "11" sehingga pada master, fasa yang didapatkan adalah "++--+-+-+" dan pada slave, fasa yang didapatkan adalah “+++++--+", sesuai dengan Gambar 3 pada bagian perancangan.

Lebar pulsa yang didapatkan dari hasil simulasi dan realisasi pada board FPGA juga sesuai dengan spesifikasi yang dirancang yaitu sebesar $300 \mu \mathrm{s}$ seperti terlihat pada Gambar 7 dan Gambar 8. Untuk delay pulsa dapat dilihat pada Gambar 9 dan Gambar 10 sebesar $700 \mu \mathrm{s}$ yang ditunjukkan oleh cursor 1299950 ns dan 1999950 ns.

\section{B. Pembangkit Envelope}

Jumlah sinyal dan jenis fasa pada pembangkitan sinyal envelope harus sama dengan keluran dari pembangkit pulsa, yaitu sembilan pulsa envelove untuk master. Karakteristik hasil yang didapatkan ditunjukkan pada Gambar 11 - 21. Pulsa envelope mempunyai amplitudo maksimum pada $\mathrm{t}=65 \mu \mathrm{s}$ seperti ditunjukkan Gambar 11 dan 12. Hasil realisasi pada Gambar 12, menunjukkan format biner "01111111" yang sebanding dengan 127 pada bilangan desimal, dimana nilai 127 adalah amplitudo tertinggi yang terbentuk pada $\mathrm{t}=65 \mu \mathrm{s}$. Lebar envelope sebesar $300 \mu$ s pada perancangan sedangkan realisasi sebesar $298 \mu \mathrm{s}$, masih mencukupi untuk menjadi pulsa envelope karena lebar envelope LORAN-C antara $200 \mu \mathrm{s}-300 \mu \mathrm{s}$.
Untuk timing yang sama, fasa envelope harus sama dengan kode fasa yang dibangkitkan oleh pembangkit pulsa. Hasil simulasi dari fasa envelope ditunjukkan pada Gambar 15, 17, 19. Terlihat pada Gambar 19, dengan bentuk analog ketika fasa positif maka terjadi puncak envelop sedangkan ketika fasa negatif terjadi lembah. Untuk realisasi pada FPGA, dilihat dari sign bit " 0 " untuk menyatakan envelope positif dan sign bit "1" untuk menyatakan envelope negatif.

Pembangkitan sinyal envelope mengikuti pulsa yang dibangkitkan generator pulsa, sehingga keluaran generator envelope harus sama dengan timing pembangkitan envelope, begitu pula dengan delay antar pulsa. Hasil simulasi yang ditunjukkan Gambar 20, didapatkan bahwa delay antar envelope sebesar $700 \mu$ s yang dibatasi cursor $1299950 \mu \mathrm{s}-1999950$ $\mu \mathrm{s}$. Pada hasil realisasi di Gambar 25 , delay antar envelope juga didapatkan nilai sebesar $700 \mu \mathrm{s}$.

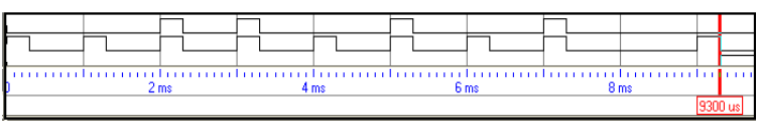

Gambar 5. Jumlah Pulsa Master Hasil Simulasi
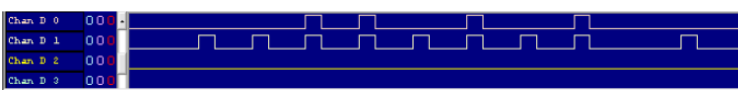

Gambar 6. Jumlah Pulsa Master Hasil Realisasi

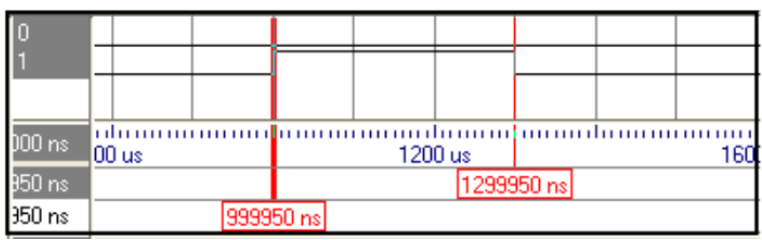

Gambar 7. Lebar Pulsa Hasil Simulasi

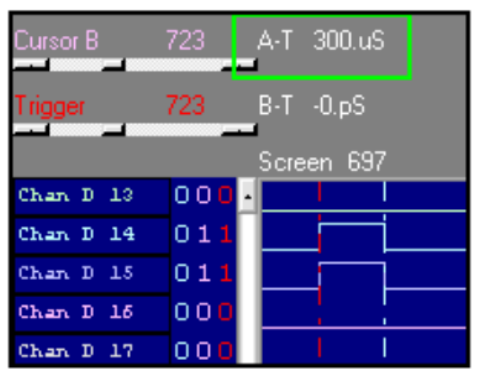

Gambar 8. Lebar Pulsa Hasil Realisasi

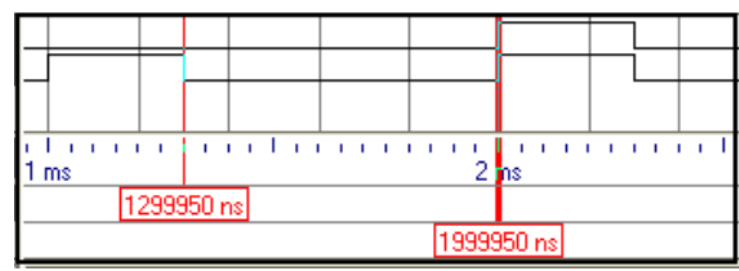

Gambar 9. Delay Pulsa Hasil Simulasi 


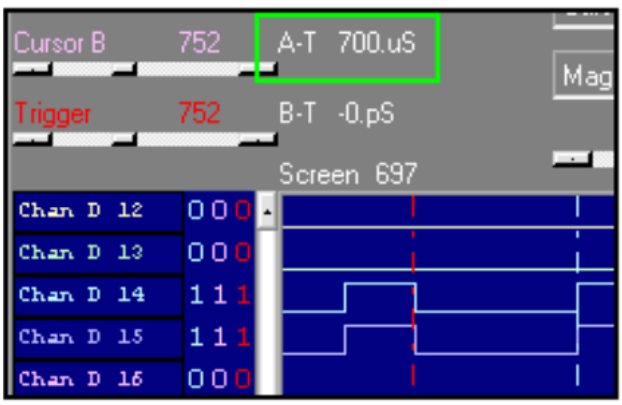

Gambar 10. Delay Pulsa Hasil Realisasi

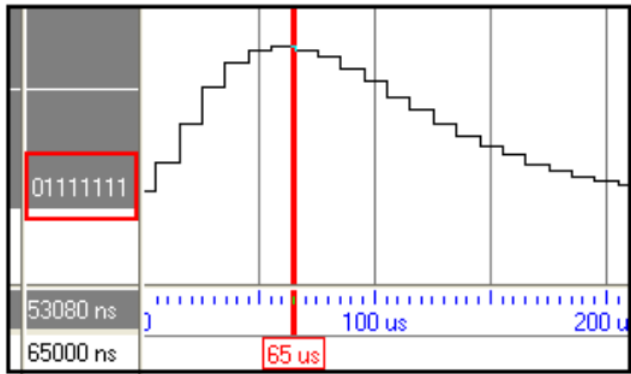

Gambar 11. Amplitudo Envelope Hasil Simulasi

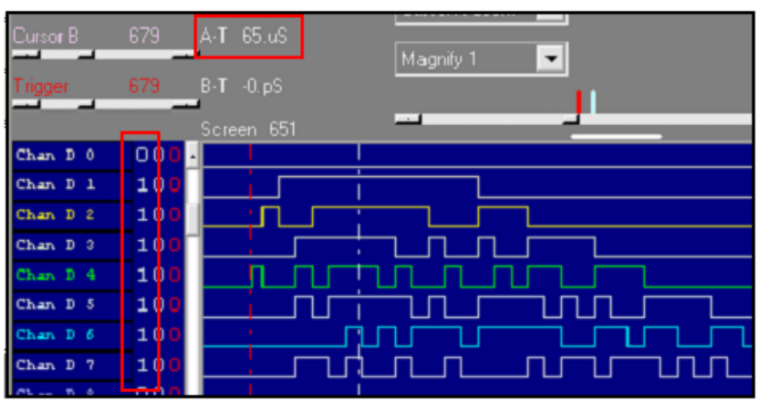

Gambar 12. Amplitudo Envelope Hasil Realisasi

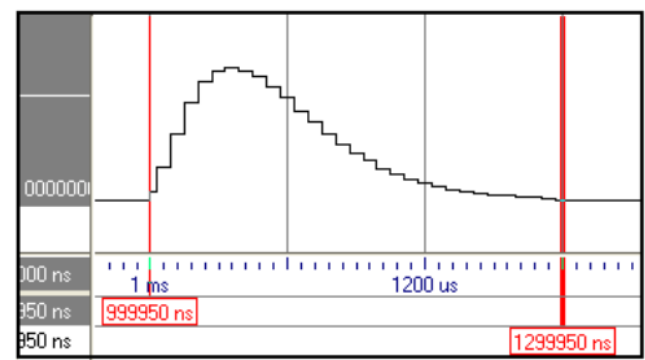

Gambar 13. Lebar Envelope Hasil Simulasi

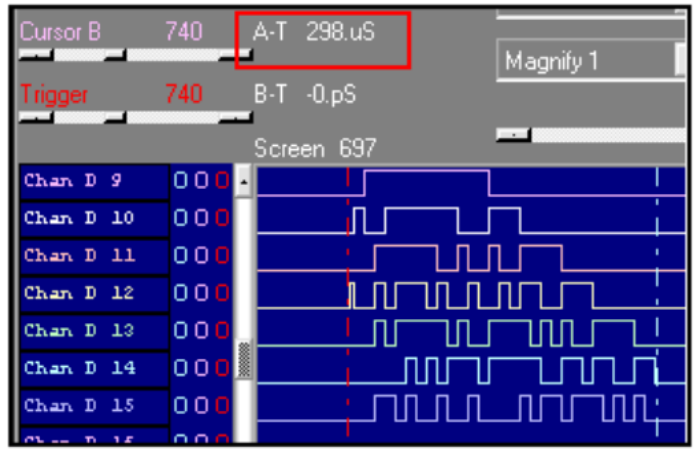

Gambar 14. Lebar Envelope Hasil Realisasi

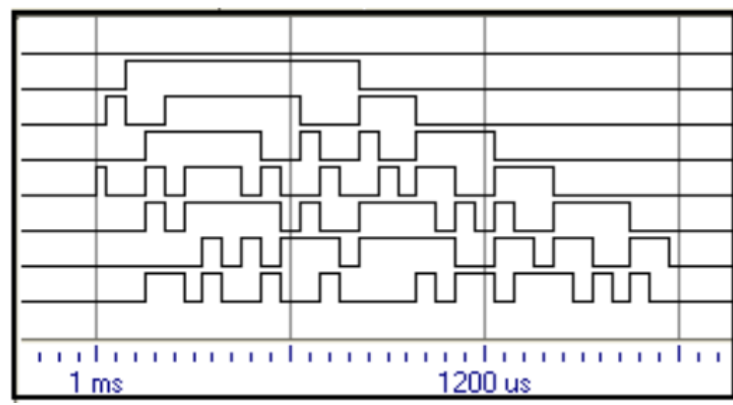

Gambar 15. Fasa Positif Envelope Hasil Simulasi

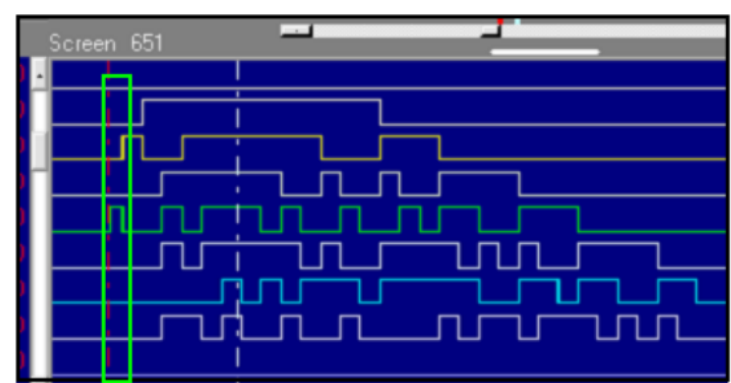

Gambar 16. Fasa Positif Envelope Hasil Realisasi

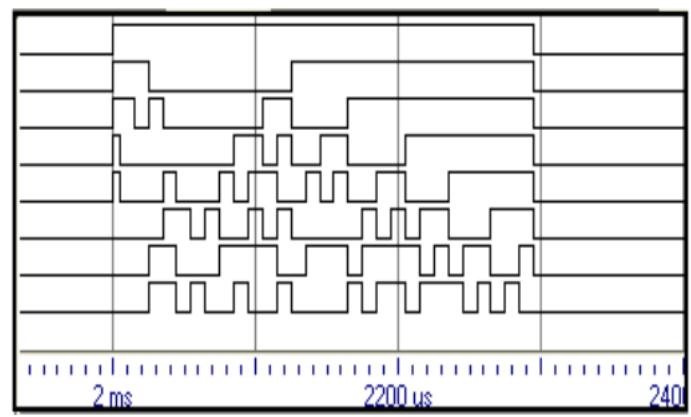

Gambar 17. Fasa Negatif Envelope Hasil Simulasi

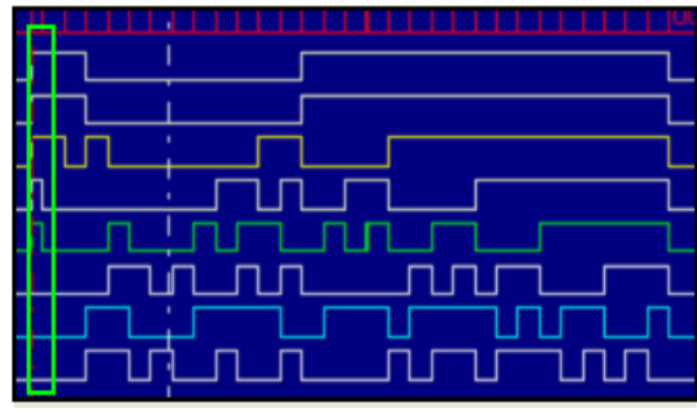

Gambar 18. Fasa Negatif Envelope Hasil Realisasi

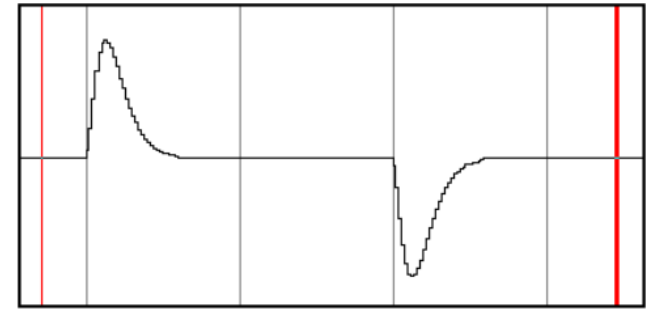

Gambar 19. Fasa Positif dan Negatif Envelope Hasil Simulasi Bentuk Analog 


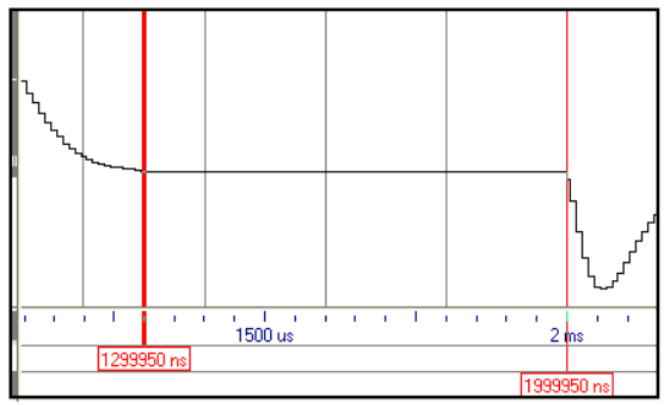

Gambar 20. Delay Envelope Hasil Simulasi

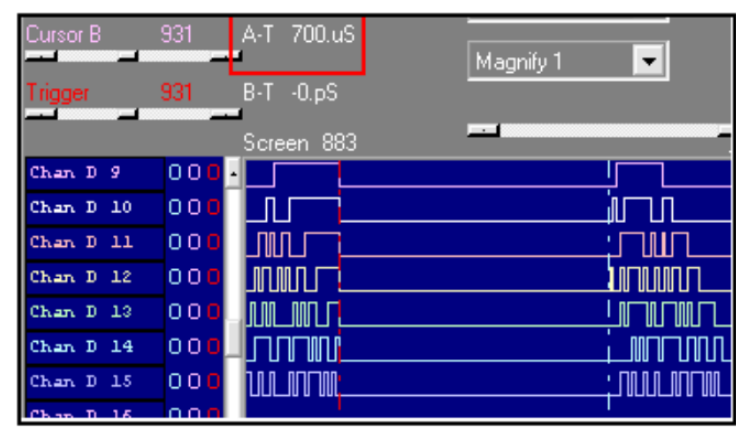

Gambar 21. Delay Envelope Hasil Realisasi

\section{Sinyal Pembawa}

Sinyal pembawa yang digunakan untuk proses modulasi mempunyai frekuensi $100 \mathrm{kHz}$. Frekuensi tersebut diperoleh dengan cara melakukan pencuplikan terhadap 3001 titik dengan menggunakan counter untuk mendapatkan bentuk seperti yang ditunjukkan pada Gambar 22. Dalam format 8 bit didapatkan frekuensi sebesar 1/10.1 us yaitu 99009,9 $\mathrm{Hz}$ untuk hasil realisasi seperti pada Gambar 24. Sedangkan hasil simulasi menunjukkan $1 / 10 \mu$ s atau $100 \mathrm{kHz}$, seperti pada Gambar 23.

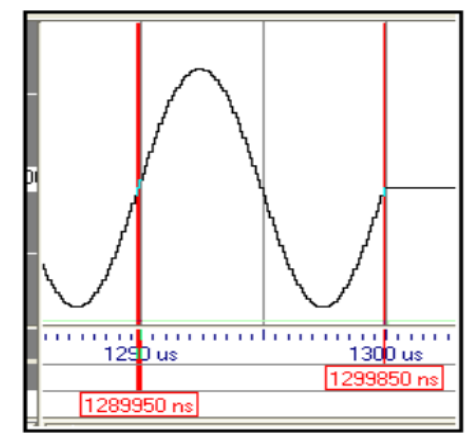

Gambar 22. Sinyal Pembawa Bentuk Analog hasil Simulasi

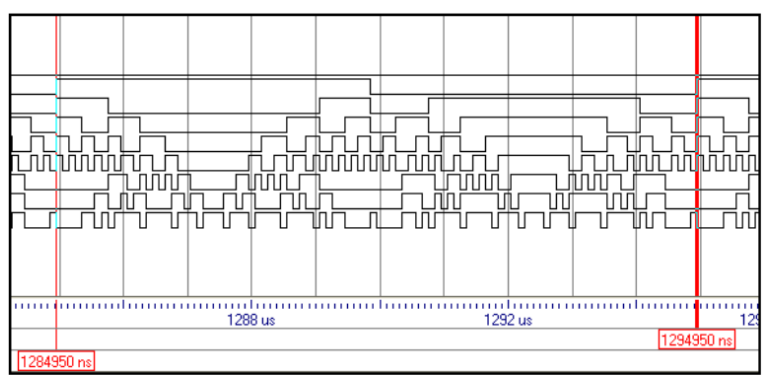

Gambar 23. Sinyal Pembawa Bentuk Digital hasil Simulasi

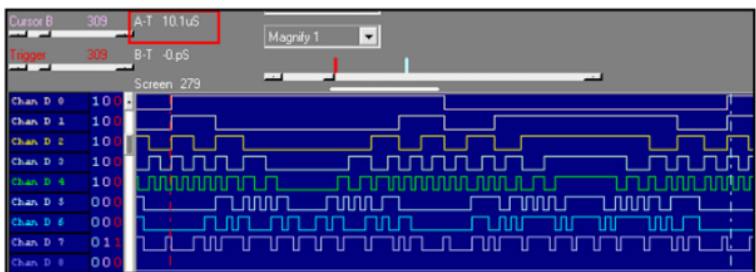

Gambar 24. Sinyal Pembawa Bentuk Digital hasil Realisasi

\section{Multiplexer}

Hasil modulasi bentuk analog ditunjukkan pada Gambar 25 untuk pulsa master, dengan hasil sembilan pulsa master. Detail spesifikasi ditunjukkan pada Gambar 26 - 35. Sebuah sinyal LORAN-C yang dihasilkan dari modulasi AM-DSB-SC ditunjukkan pada Gambar 26, bentuk sinyal menyerupai envelope yang diisi oleh sinyal pembawa dengan frekuensi 100 kHz. Amplitudo tertinggi didapatkan pada 62747 ns pada simulasi dan pada hasil realisasi didapatkan bit "0011011100010001" yang terbentuk pada $\mathrm{t}=62,5$ $\mu$ s. Untuk lebar pulsa hasil simulasi sebesar 295987 ns ditunjukkan pada Gambar 29, dan lebar pulsa hasil realisasi sebesar $298 \mu$ s ditunjukkan pada Gambar 35.

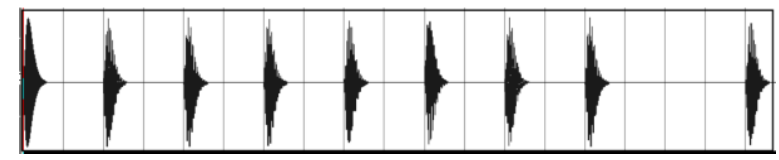

Gambar 25. Grup Pulsa Master Hasil Simulasi

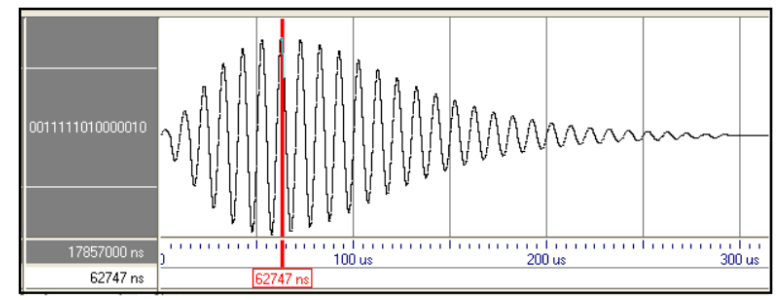

Gambar 26. Amplitudo Sinyal LORAN-C Bentuk Analog Hasil Simulasi

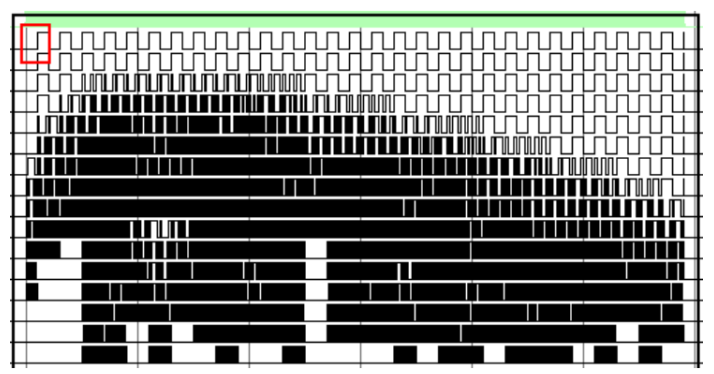

Gambar 27. Amplitudo Sinyal LORAN-C Bentuk Digital Hasil Simulasi 


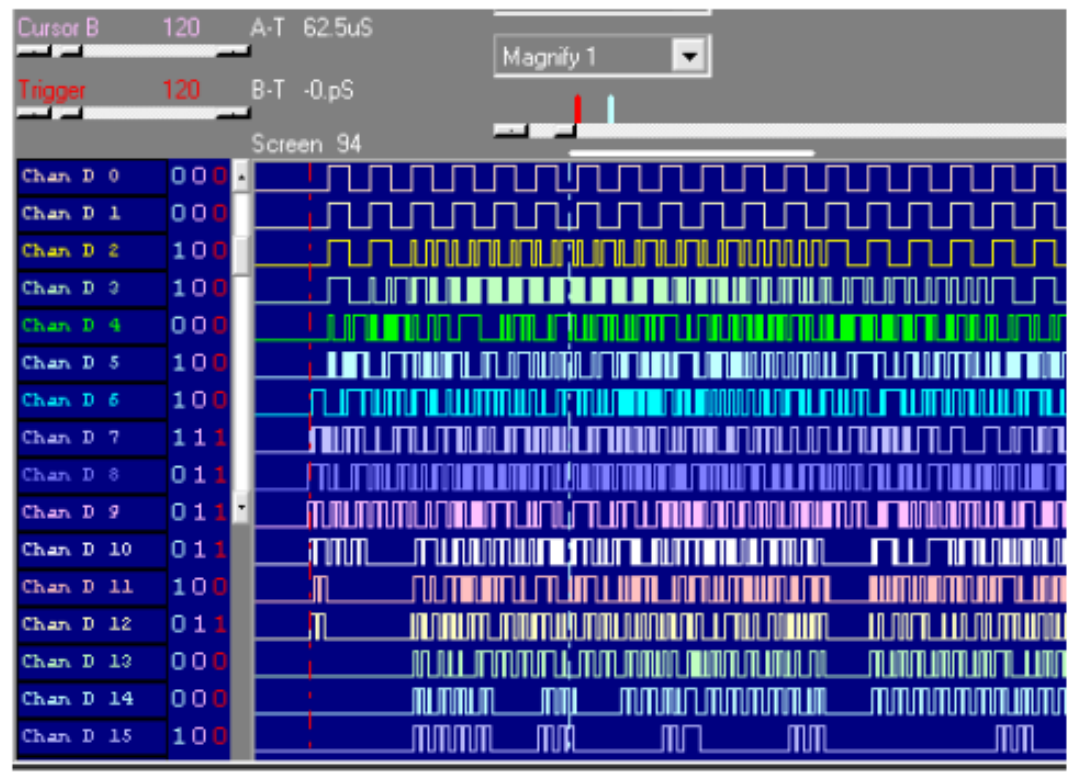

Gambar 28. Amplitudo Sinyal LORAN-C Bentuk Digital Hasil Realisasi

Fasa dalam bentuk analog yang didapatkan dari hasil modulasi ditunjukkan pada Gambar 31. Fasa negatif, secara analog, ditunjukkan dengan siklus turun pada amplitudo awal dan fasa positif ditunjukkan dengan siklus naik pada amplitudo awal. Hal ini seuai dengan keluaran dari pembentukan sinyal envelope untuk fasa negatif dan positif. Pada bentuk biner, seperti yang ditunjukkan pada Gambar 32 - 35, dengan sign bit " 1 " untuk fasa negatif dan sign bit " 0 " untuk fasa positif.

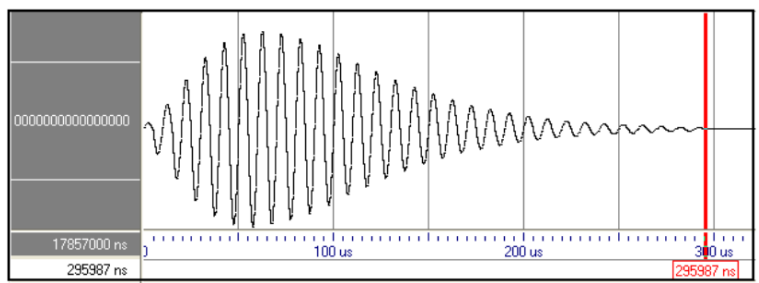

Gambar 29. Lebar Simyal LORAN-C Bentuk Analog Hasil Simulasi

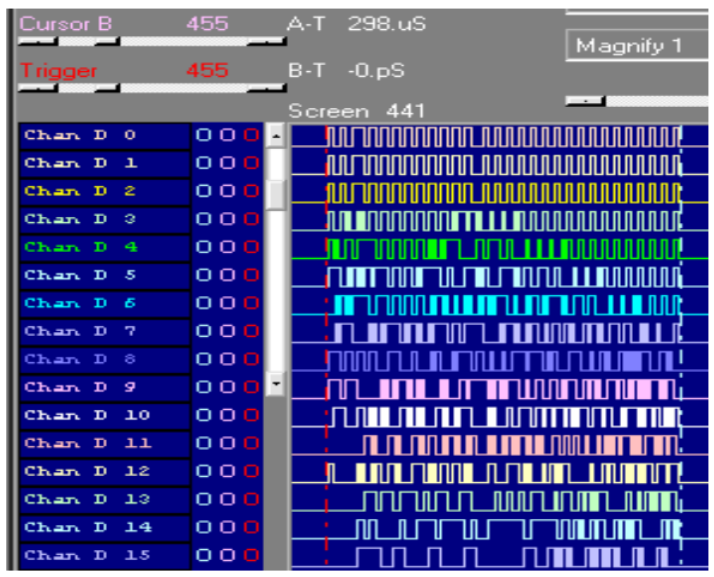

Gambar 30. Lebar Sinyal LORAN-C Bentuk Digital Hasil Realisasi
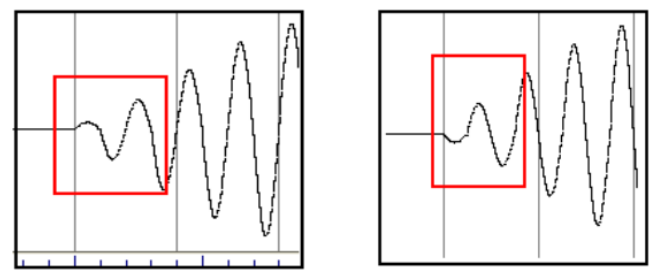

Gambar 31. Fasa Positif dan Fasa Negatif Bentuk Analog Hasil Simulasi

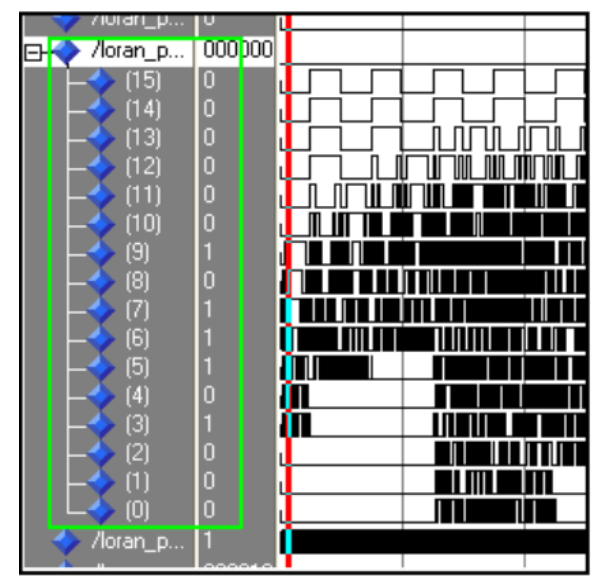

Gambar 32. Fasa Positif Bentuk Digital Hasil Simulasi 


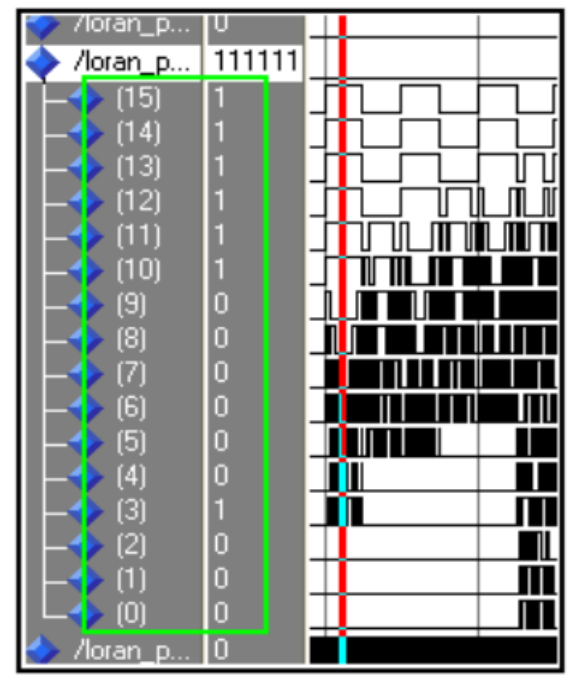

Gambar 33. Fasa Negatif Bentuk Digital Hasil Simulasi

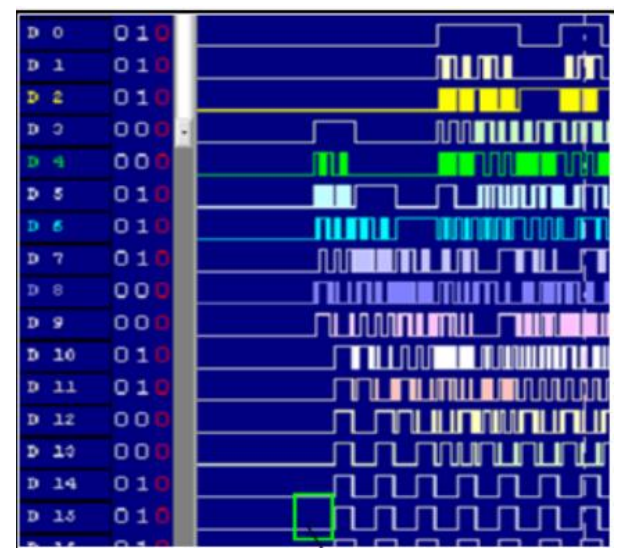

Gambar 34. Fasa Positif Bentuk Digital Hasil Realisasi

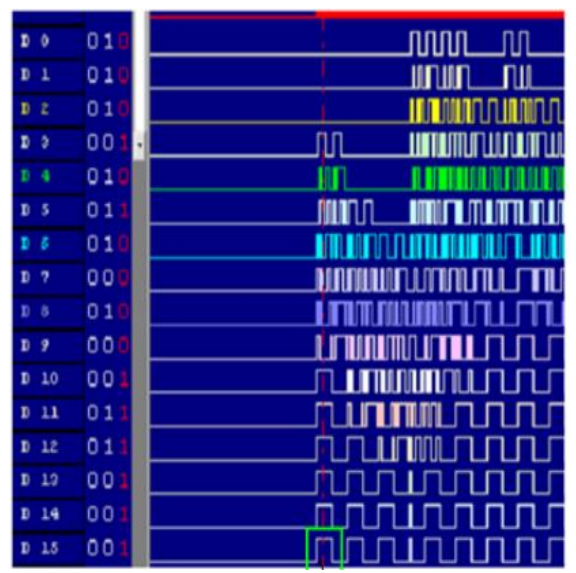

Gambar 35. Fasa Negatif Bentuk Digital Hasil Realisasi

\section{PENUTUP}

\section{A. Kesimpulan}

Dari penelitian yang telah dilakukan maka dapat diambil kesimpulan bahwa proses pembangkitan pulsa LORAN-C untuk stasiun master diperoleh hasil sebagai berikut, lebar pulsa $300 \mu \mathrm{s}$, delay pulsa 700 $\mu \mathrm{s}$, amplitudo maksimum pada $\mathrm{t}=60-65 \mu \mathrm{s}$ dengan fasa dan jumlah pulsa sesuai dengan spesifikasi sistem navigasi LORAN-C.

\section{B. Saran}

Untuk mengembangkan penelitian lebih lanjut, maka dapat dilakukan beberapan saran berikut.

1. Merancang pemancar slave untuk membuat sistem triangulasi agar dapat menentukan posisi dari objek.

2. Layanan pada sistem LORAN-C dapat ditambahkan dengan layanan timing dan paging, bukan hanya navigasi.

3. Perancangan dan realisasi dilanjutkan bukan hanya dilevel baseband namun sampai ke level blok RF mencakup pembuatan ADC, up converter, RF Filter serta amplifier.

\section{DAFTAR PUSTAKA}

[1] Central Intelligent Agencies, "The World Factbook: East and South East Asia: Indonesia." [Online]. Available:

https://www.cia.gov/library/publications/the-worldfactbook/geos/id.html. [Accessed: 03-Mar-2016].

[2] H. J. Kramer, Observation of The Earth and Its Environment - Survey of Missions and Sensors 4th Edition, 4th Editio., vol. 19, no. 1. Springer-Verlag, 2002.

[3] United States Coast Guard, "Specification of The Transmitted LORAN-C Signal," Washington, DC., 1994.

[4] G. Lachapelle, B. Townsend, H. Gehue, and M. E. Cannon, "GPS versus Loran-C for vehicular navigation in urban and mountainous areas," in Proceedings of VNIS '93 - Vehicle Navigation and Information Systems Conference, 1993, pp. 10-13.

[5] J. Carroll, "GPS + LORAN-C Performance Analysis of an Integrated Tracking System," no. July, pp. $40-$ 47, 2006.

[6] J. \& BAILEY, "the Loran-C System of Navigation," no. February, p. 135, 1962.

[7] R. L. Frank, "Current Developments in Loran-C," in Proceedings of the IEEE, 1983, vol. 71, no. 10, pp. 1127-1139.

[8] US Coast Guard Navigation Center, "Loran-C User's Handbook," 1992.

[9] A. J. Fisher, "The Loran-C Cycle Identification Problem," pp. 1-20, 1999.

[10] L. W. Couch, Digital and Analog Communication Systems 8th Edition. 2013.

[11] J. D. Krauss, Antennas. McGraw-Hill Book Company, 1950. 